\title{
Comparative Study of Education Funding in Nigeria
}

\author{
Edward Agbai $^{1^{*}} \quad$ Anthony Okafor $^{2} \quad$ Funminiyi Egbedoyin $^{3}$ \\ 1.School of Management, Emmanuel University, Fayetteville, NC 28311, USA \\ 2.School of Accountancy, University of Louisville, KY, USA \\ 3. School of Management, Walden University, Minneapolis, MN 55401, USA \\ * E-mail of the corresponding author: edwardagbai@gmail.com
}

\begin{abstract}
This study provides a comparative review of education funding across geopolitical zones in Nigeria and draws a nexus between Nigeria's budgetary allocation to education and some selected African countries. Education funding in Nigeria has lagged the UNESCO's advised 15\%-20\% of the government's annual budget to education in the last three decades. We assess education funding across the six geopolitical zones between 2010 and 2019 using content analysis of the respective states. A review of the WAEC enrollment for states in each zone is performed to compare how education funding impacts WAEC enrollment in Nigeria. The study identifies a link between poverty and income inequality and education funding in Nigeria by leveraging data from the World Bank and Nigeria Bureau of Statistics (NBS) from 2001-2019. We identify low funding of education as the primary driver of poverty and inequality in Nigeria. The study recommends a diversified funding mechanism to enhance the sector's funding and improve the quality of education in the country.
\end{abstract}

Keywords: Education Funding, Poverty and Inequality, Nigeria

DOI: $10.7176 / \mathrm{JEP} / 12-5-01$

Publication date: February $28^{\text {th }} 2021$

\section{Introduction}

Inadequate funding remains a significant challenge facing the education sector in Nigeria and has persisted for decades. Funding of the education sector in the last 20 years has lagged the $15-20 \%$ suggested benchmark prescribed by the United Nations Educational, Scientific and Cultural Organization (UNESCO). UNESCO commissioned the Education for All (EFA) $(2000$ - 2015) project to recommend funding for education by various countries. In their recommendation, Education for All canvassed for a significant increase in education funding and national governments' financial commitment to accelerate growth in the sector.

Developed nations owe most of their successes to substantial investments in made education over the years (King, 2011). Countries invest in education for several reasons, with the recurring purpose being skills acquisition to drive critical sectors of the economy, wealth creation, strengthen democracy, and the smooth running of society. The decline in the education sector became noticeable in the late 1990s when the government began starving the sector of funds (Taiwo, 2019). The period was also plagued with incessant and prolonged strikes by university lecturers, which began under the military regime in the 90 s to the present day over poor teaching conditions and lack of infrastructure to enhance teaching and learning. The proliferation of academic institutions, government's waning interest in funding education, and the excessive quest for foreign certificates accelerated the decline of the education sector.

Coincidentally, Nigerians became more impoverished, and instances of inequality became prevalent during the period. Specific indicators show whether a country is poor, ravaged by poverty, or inequality. These indicators include Income inequality, GDP per Capita, access to education, poverty rate, poverty gap, discriminatory family code, and house crowding. Other indicators include violence against women, the number of women in politics, and the strength of social institutions (Gordon, 2005; OECD, 2019). The uneven economic fortunes and inequalities in the society are highly evident in the access to education and basic amenities of life.

In 2019, at the World Economic Summit, it was declared that about 90 million Nigerians live in extreme poverty, according to estimates from the World Data Lab's Poverty Clock. It is established that the root cause of poverty lies in the deprivation of people's access to necessities such as food, healthcare, education, and access to finance, amongst others. In his book, "Poverty and Famines: An Essay on Entitlement and Deprivation," Sen (1983) equates poverty to income inequality and access to education. To determine the drivers of poverty and inequality in Nigeria, we focus on budget funding for education by governments and access to educational facilities across Nigeria. Therefore, this study provides a perspective to understanding the drivers of poverty and inequality in Nigeria using education funding as a guide.

The purpose of this study is to provide a comparative analysis of education funding across geopolitical zones in Nigeria and to draw a nexus between Nigeria's budgetary allocation to education and some selected African countries, namely Ghana, Rwanda, and South Africa. The essence of this is to identify a link between education funding and poverty levels in the selected countries. To interrogate this further, we examine whether state governments' financing of the education sector affects poverty in the respective states. In addition, we 
utilize WAEC enrolments as a metric to assess the extent to which the low budgeting for education below $20 \%$ UNESCO benchmark exacerbates poverty levels in Nigeria.

While it is well documented that Nigeria has enjoyed rapid economic growth in the last 30 years, the same cannot be said of the extent to which this economic growth has improved employment, reduced poverty, and inequality in the country (Tade, 2020). Several studies have investigated issues about growth, poverty, and inequality in Nigeria (Kolawole, Omobitan, \& Yaqub, 2015: Tade, 2020). However, education funding and its relation to poverty and inequality have somewhat been neglected in the literature. The remaining sections of this paper are structured as follows: Section 2 contains a comprehensive review of the literature. In section 3, we provide a comparative analysis of education funding in Nigeria across the different geopolitical zones and some selected African countries. Section 4 contains a summary of our findings, recommendations, and conclusion.

\section{Literature Review}

This study provides a comparative review of education funding across geopolitical zones in Nigeria and draws a connection between Nigeria's budgetary allocation to education and some selected African countries. The study provides a detailed review of education funding of twelve states in Nigeria, two states selected from each of the six geopolitical zones for ten years between 2009 and 2019. In addition, we evaluate how education funding has impacted student's enrollment in the West African Examination Council exams during the period.

\subsection{Poverty and Inequality in Africa}

The consequential effect of economic growth in an economy is the ability to gain sufficient traction that allows it to reduce poverty and inequality (Kinyondo \& Pelizzo, 2016). While Nigeria has witnessed economic growth in the past decade, such growth has had little or no impact in bridging the inequality and poverty in the country. Poverty is a significant phenomenon in developing countries (DCs) and less developed countries (LDCs), and Nigeria being a developing country, is a significant contributor to the poverty indices in Africa. This is not unconnected with its sheer population size of 206 million people, with over 90 million people living below the extreme poverty line (World Bank, 2018). Poverty reduction can be achieved in developing countries and less developed countries by implementing policies to narrow the income inequality gap in the country. Within the context of available literature, four areas have received significant attention with regards to poverty.

The first school of thought deals with poverty as a concept, which is broken into two components (Davis \& Sanchez-Martinez, 2015). This school of thought is anchored on two components; the first component attributes poverty to poor economic circumstances caused by the individual's own choices. It presupposes that a combination of self-motivation, determination, and persistence could move the individual out of poverty to financial stability. The second component focuses on socioeconomic sub-cultures that develop in certain population segments. It accentuates the idea that low-income working-class groups create and maintain certain attitudes, beliefs, and perspectives that keep them within the poverty bracket rather than seek better alternatives. This is observable in welfarist societies where citizens prefer welfare packages than taking up full-time jobs. Another component attributes poverty to inequalities perpetuated through political, economic, and social systems. Others are driven by corruption, nepotism, and discriminatory access to education (Davis \& Sanchez-Martinez, 2015). These place a particular segment of the population at a disadvantage in getting jobs and having access to social amenities. Examples abound amongst immigrant population in some developed countries.

The second category focuses on how to measure poverty. Poverty can be measured by comparing an individual's income to some poverty thresholds or the minimum amount required to meet basic needs (Butler, 2018). Other measures of poverty include using a cut-off point in relation to the overall distribution of income or consumption in a country using a national poverty indicator or the official poverty measure. The national poverty indicator measures an individual's ability to access the set of goods and services needed to live a decent life in the society to which they belong (Feng, 2014). The third view spotlights the causal factors for poverty. The causes of poverty are categorized into behavioral, structural, and political factors. Individual behavioral factors are driven by incentives and cultural affinity, while the structural factors consider both demographic and labor market paradigms. The political factor contends that political power and authority vested in institutions of the state formulate policies that cause poverty (Brady, 2019).

The fourth school of thought elicits discussions on the means of ending poverty (Shweta, 2018). These means include creating awareness through social media, individuals funding a poor child's education, and donating money to a non-profit organization with a mandate to help the poor. Other suggested means of ending poverty include educating everyone, eliminating gender inequality by promoting girl-child education, and teaching non-literate people skills to make them employable (Mitana et al. 2018, Shweta, 2018).

Consequently, increasing public and private education funding will ensure education for most of the population, especially the girl-child, thereby increasing their productive capacity and reducing poverty. As seen above, research efforts have focused on the thematic areas of poverty, inequality, and suggestions on improving economic growth. However, there has been a limited intervention on how increased public funding of education 
affects poverty (Abideen et al. 2013; Mitana et al. 2018). Thus, we are expanding the discussion to assess how the limited funding of education increases poverty levels in Nigeria.

\subsection{Poverty Indices in Nigeria and selected States}

In a recently published report, the World Poverty Clock reported that Nigeria overtook India as the country with the most extremely poor people in the world. India has a population seven times larger than Nigeria, so how can such a conclusion be justified? Unfortunately, available data justifies this assertion. The inability to lift more citizens out of extreme poverty is an indictment on successive Nigerian governments, which have mismanaged the country's vast oil and gas resources through bad leadership, incompetence, and corruption (Akpan \& Isihak, 2020; Omodero, 2019).

All the regions of the country have a fair share of the poor; however, the majority of the poor are in the Northern part of the country. If Nigeria is the world's poverty capital, the north, by extension, is Nigeria's poverty capital (Amechi, 2020; Arndt et al. 2016). The extreme poverty in the north, especially the North-East, is linked to the insecurity that has engulfed the region, crippling economic activities in the last decade (Arndt et al. 2016).

Figure 1 shows the poverty headcount rate and poverty gap indices in Nigeria measured using the Gini coefficient, the Poverty Gap Index, and the Poverty Headcount Rate. Gini coefficient is a measure for income inequality within the population and condenses a country's income distribution between 0 and 1; the higher the value tends to 1 , the greater the degree of inequality within the country and vice versa. The poverty headcount rate is the percentage of the population living below the poverty line in the country. The estimates are based on population-weighted subgroup estimates of households from the Nigeria Living Standard Survey 2018-2019 released in July 2020 by the Nigerian Bureau of Statistics in collaboration with the World Bank. The poverty gap index is a measure of the intensity of poverty that compares the average poverty gap in the population and the poverty line. A combination of these measuring tools is used to assess the poverty level in Nigeria's rural and urban centers.

Figure 1. Poverty headcount rate and Poverty gap indices in Nigeria

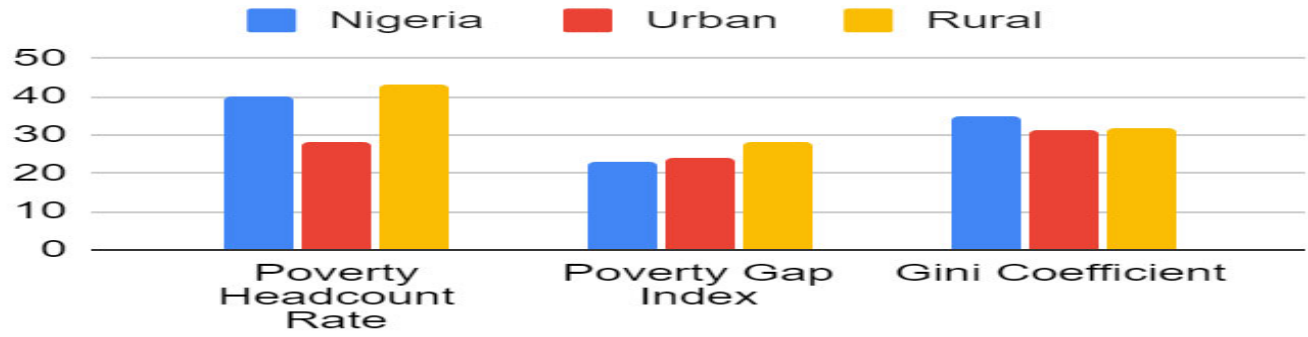

Source: Nigeria Bureau of Statistics (NBS)

As shown in Figure 1 above, in 2019, the average Nigerian poverty headcount rate was about $40 \%$, with about $18 \%$ in the urban center and $52 \%$ in the rural areas. The poverty gap index for Nigeria was about $13 \%$, $4 \%$ in the urban areas, and $17 \%$ in the rural areas between 2010 and 2019;2019 was selected to assess the results of various national and sub-national government funding on education and its corresponding impact on poverty within the ten years period. The Gini coefficient, which measures the statistical dispersion for income inequality or wealth inequality, was $35.1,31.9$, and 32.8 for Nigeria, urban centers, and rural areas.

Figure 2. Poverty headcount rate and Poverty gap indices (from the selected States in Nigeria)

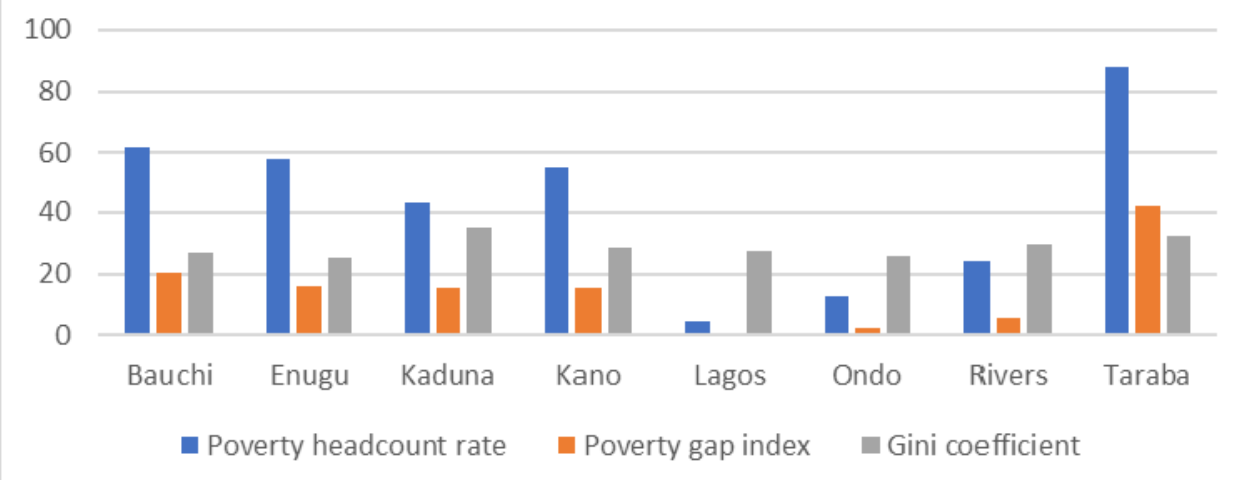

Source: Nigeria Bureau of Statistics

As shown in figure 2, the poverty headcount in Bauchi state was $62 \%, 88 \%$ in Taraba state, and $43 \%$ in 
Kaduna state. The poverty gap index in Bauchi was $20.50 \%, 42.38 \%$ in Taraba state, and $15.51 \%$ in Kaduna state (Bauchi and Taraba are states in the North East ravaged by terrorism and insurgency). The Gini coefficient was 27, 32, and 35 in Bauchi, Taraba, and Kaduna states, respectively. The poverty headcount and poverty indices show that states in the northern part of the country were above the national average compared to states in the South. Southern states of Edo, Lagos, and Rivers had poverty headcounts of 12,5 , and 23, below the national average of 40 .

\subsection{Education Funding in Nigeria}

Education funding remains a challenge in Nigeria, and budgetary allocations vary significantly across the states and regions. Across the six geopolitical zones in 2019, the South-West region had the highest combined budget at about N2.01trillion, followed by the South-South with N1.97trillion. The North West had N1.05triliion, North Central, N894.34billion, and the South East with circa N870.0billion. The North-East region had the lowest combined budget of about N676billion. Education funding in Nigeria is a function of the overall budget. Given the huge differences in the yearly budgets across the regions, it is apparent why some region's illiteracy levels remain high. Low literacy level in the Northern part of the country is responsible for the insurgency, which has significantly ravaged the entire North-East geopolitical zone in the last decade.

Adequate funding for education is necessary for reducing poverty because education provides the pathway towards developing human capacity and activities that will create economic opportunities. This economic opportunity, when properly harnessed, is what leads to wealth creation. Wealth must first be created before it can be distributed; wealth creation comes from being aware of the challenges and business opportunities within a country and only comes through education (Amechi, 2020). Yearly budgetary allocations to education at the subnational levels have been abysmally low, significantly trailing UNESCO's recommended benchmark of 15-20\%. As opined by Kamau et al. (2017), a budget and the budgeting process is a framework within which nations and individuals align plans with a practical set of processes and procedures to meet specific goals. It provides a road map to the desired destination, with some degree of certainty, but successive governments have continuously allocated meager sums to the education sector. This contrasts with UNESCO's recommendation, thereby hampering access to education and its attendant problems of unemployment, poverty, and inequality.

In examining the budgetary allocations and access to education at the sub-national level, we review education funding and WAEC enrollments across the regions. The two states selected from each geopolitical zone include Benue and Kwara states from the North Central, Bauchi and Taraba states from the North East, Kaduna, and Kano states from the North West, Ebonyi and Enugu states in the South East, Edo and Rivers states from the South-South, while Lagos and Ondo states were selected from the South West. The states were chosen on two criteria, one as the highest budgeting state in the geopolitical zone as shown in table 1. The second criteria are states with the lowest budget for education in the geopolitical zones, as shown in table 2 . We reviewed the education budget as a percentage of the states' annual budget between 2009 and 2019 and WAEC enrollment figures between 2016 and 2018 as obtained from the NBS database.

Table 1: States with the highest budget in each geopolitical zone and percentage of education funding

\begin{tabular}{|l|l|l|l|l|l|l|}
\hline Year & Enugu & Rivers & Bauchi & Lagos & Kano & Kwara \\
\hline 2010 & 13.0 & 16.0 & 6.8 & 18.41 & 20.0 & 6.26 \\
\hline 2011 & 16.0 & 13.2 & 5.72 & 13.9 & 3.29 & 10.84 \\
\hline 2012 & 16.0 & 10.3 & 14.01 & 12.65 & 2.61 & 9.72 \\
\hline 2013 & 16.0 & 3.72 & 9.2 & 12.20 & 3.65 & 25.0 \\
\hline 2014 & 6.21 & 6.18 & 5.38 & 15.81 & 9.89 & 17.04 \\
\hline 2015 & 6.30 & 2.59 & 5.55 & 16.8 & 13.14 & 25.0 \\
\hline 2016 & 10.41 & 15.13 & 19.73 & 17.11 & 19.18 & 7.04 \\
\hline 2017 & 12.0 & 6.38 & 20.0 & 7.14 & 8.16 & 6.97 \\
\hline 2018 & 12.01 & 9.80 & 18.8 & 12.07 & 12.57 & 9.72 \\
\hline 2019 & 10.35 & 11.25 & 5.43 & 12.0 & 14.02 & 17.94 \\
\hline
\end{tabular}

Source: Nigeria Bureau of Statistics 
Table 2: Random Selection of States in each geopolitical zone and percentage of education funding

\begin{tabular}{|l|l|l|l|l|l|l|}
\hline Year & Ondo & Kaduna & Benue & Ebonyi & Edo & Taraba \\
\hline 2010 & 6.18 & 27.0 & 10.01 & 10.13 & 13.0 & 11.12 \\
\hline 2011 & 5.71 & 18.2 & 10.89 & 11.15 & 11.6 & 10.90 \\
\hline 2012 & 5.51 & 7.44 & 5.25 & 9.93 & 5.03 & 9.98 \\
\hline 2013 & 6.96 & 7.17 & 9.4 & 10.07 & 17.79 & 26.0 \\
\hline 2014 & 6.79 & 15.68 & 11.2 & 19.29 & 12.83 & 9.04 \\
\hline 2015 & 8.86 & 15,7 & 11.7 & 8.86 & 9.49 & 5.55 \\
\hline 2016 & 9.70 & 19.91 & 12.2 & 5.03 & 8.62 & 4.76 \\
\hline 2017 & 10.6 & 21.25 & 12.0 & 6.02 & 8.18 & 4.9 \\
\hline 2018 & 14.46 & 25.0 & 12.61 & 8.86 & 4.88 & 5.17 \\
\hline 2019 & 5.15 & 17.42 & 10.65 & 7.61 & 5.22 & 6.92 \\
\hline
\end{tabular}

Source: Nigeria Bureau of Statistics

Figure 3: Percent of Education Funding in the Selected States

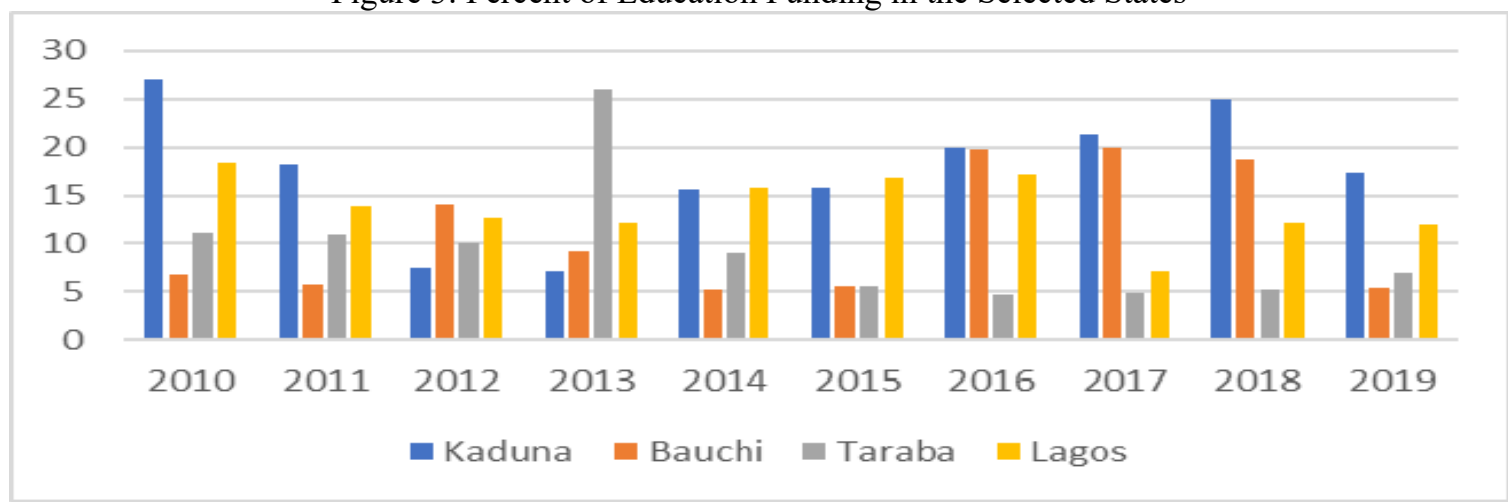

Source: Nigeria Bureau of Statistics

Tables 1 and 2 show the percent of education spending in relation to budget across the states selected from each geopolitical zone. A review of the data indicates that Kaduna state increased education funding significantly between 2015 and 2019, even above the UNESCO benchmark. The state seems to be making giant strides in education and reversing the decline in education in northern Nigeria. The resources allocated to education rose significantly except for 2019 that witnessed a decline. In 2015, the state allocated $16.0 \%, 20.0 \%$ in 2016, and exceeded UNESCO's benchmark in 2017 and 2018 with $22.0 \%$ and $26 \%$, respectively.

As shown in figures $3 \& 8$, the states' hover around the national average on the poverty headcount rate, poverty gap index, and Gini coefficient around 8-15 percent when compared with 40.09, 12.85, and 35.13 respectively in 2019. Bauchi state reached $20.0 \%$ in 2017 but reversed the trend subsequently by allocating an average of $14.0 \%$ to education between 2015 and 2019 . The state fell below the national average on the poverty headcount rate, poverty gap index, and Gini coefficient between 40-60 percent when compared with 40.09, 12.85, and 35.13 , respectively, in the national average in 2019.

Similarly, Taraba state reached a peak of $26 \%$ in 2013 but failed to sustain the momentum and managed to average $9.43 \%$ in education funding between 2010 and 2019. Even more worrisome, when we focus on $2015-$ 2019 , the average allocation to education was $5.4 \%$. The state trailed the national average on the poverty headcount rate, poverty gap index, and Gini coefficient with over 80 percent when compared with 40.09, 12.85, and 35.13, respectively, which was the national average in 2019.

Nigeria's poverty level has been increasing over the same period standing at $70 \%$, with $42.6 \%$ in the North Central, while the North East and North West regions accounted for $76.8 \%$ and $81.0 \%$, respectively (Arndt et al. 2016; Ravallion, 2008). Poverty levels in the South West stood at 19.3\%, 27.3\% in the South East, and $25.2 \%$ in the South-South. 
Figure 4: WAEC enrolment for Public School in Nigeria (2016-2018)

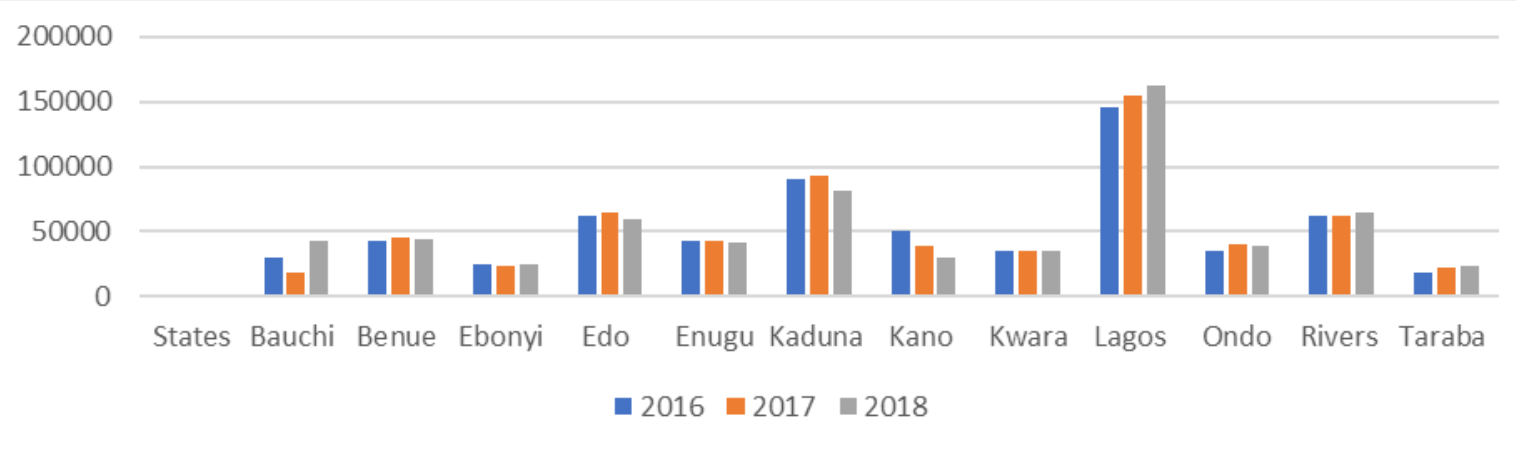

Source: Nigeria Bureau of Statistics

As shown in figure 4, data from WAEC shows that Taraba state registered 18,583 students in 2016 for the May/June exams, which increased by $17 \%$ in 2017 and $29 \%$ in 2018. Bauchi state enrolled 29,514 students in 2016 for the same exam and saw a $40 \%$ decline in 2017. The trend was reversed in 2018 by increasing enrollment by $42 \%$. The drop in WAEC enrollment in 2017 for Bauchi state may not be unconnected to the adoption of school children and foreign aid workers in 2017 in Bauchi state and other parts of the North-East between 2016 and 2017 (Ibrahim and Mukhtar, 2017).

Kaduna state registered 90,614 students in 2016, experienced a 2\% increase in enrollment in 2017 and a decline of about $10 \%$ in 2018. Interestingly, WAEC registration in Kaduna state is twice the figure recorded for Bauchi and Taraba put together for each of the years under review. Aligning the enrollment figure with the population of the states provides further insights. Based on figures from the Nigerian Population Commission, Kaduna state population was 8.2 million in 2016 that of Taraba state was 3.1 million in 2016, while Bauchi state had a population of 6.5 million in 2016. The combined population of Bauchi and Taraba states in 2016 was 9.6 million, higher than the 8.2 million people in Kaduna state. This underscores the fact that Kaduna state made significant progress in this regard.

It is instructive to note that Bauchi and Taraba states are North-Eastern states that have witnessed insurgency and criminality for over a decade. Kaduna state has had its share of banditry but has not prevented the state from prioritizing education understanding the importance of education in human capital development and growth. Lagos state consistently allocated 15\% to funding education between 2010 and 2019, which accounts for the high enrollment figures seen in WAEC examinations. Lagos enrolled 145,186 students in 2016, increased by 9,000 in 2018 representing a $6 \%$ growth. WAEC enrollments in Lagos are higher compared to other states, primarily because of its population.

\subsection{Education Funding and Poverty}

Despite efforts to reduce the high rate of unemployment and poverty in Nigeria by government agencies (Oshewolo, 2010; Surajo \& Karim 2016), poor funding remains the albatross for Nigeria's education sector and has been responsible for the many ills that have dogged the sector in the last thirty years (Ndujihe, 2019). Evidently, the condition is gloomier now because of the acute revenue shortages and the economic challenges the country is facing. Funding of education is the primary responsibility of government, although we have observed an appreciable increase in private sector-led contribution to the education sector. Across the country, investors are entering the education space to bridge the funding gap and invest in private schools right from kindergarten to the university level (Day, 2019). Job creation and poverty reduction are linked to quality education. Simpson et al. (2004) infer that the growing number of educated people going into business is a positive indication of the role of education in job creation, as seen in developed nations. 
Figure 5: Poverty Headcount Rate by Education Attainment and Sex

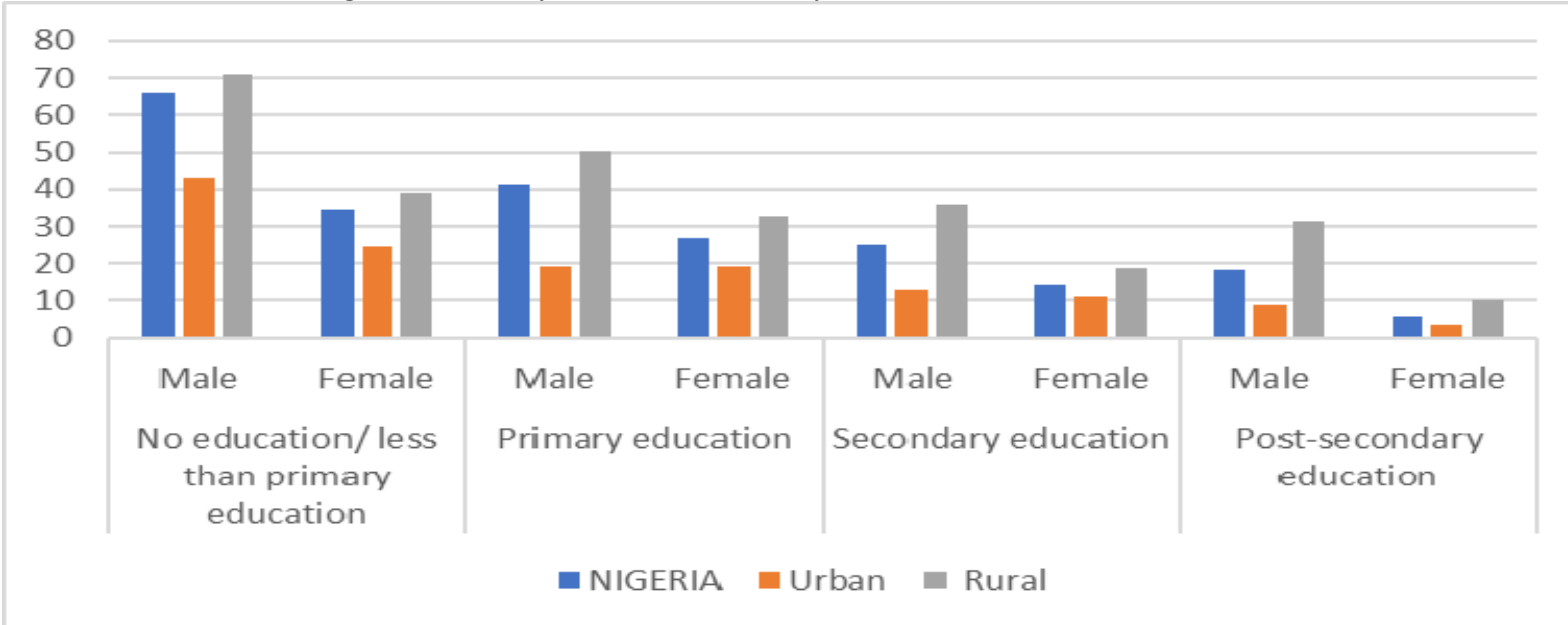

Source: Nigeria Bureau of Statistics

Education is an enabler for job creation and employment opportunities as it equips the individual with the required skill sets and the technical know-how to start their businesses (Mourshed, Farrell \& Barton, 2018). The Nigeria Living Standards Survey - 2018/2019 conducted by the NBS, as shown in Figure 5, indicates that the lower the level of educational qualifications, the more the poverty level. On average, in Nigeria, there are $66 \%$ males and $34 \%$ of females with no primary education. As the level of education increases from primary to postsecondary education, the ratio of male to female tends toward $2: 1$, which implies that for every two males in secondary school, there is one female per household in Nigeria both at the national, urban, and rural levels.

Elsewhere, in a report by Partner Work in 2018, which reviewed data of 90,000 job seekers in public workforce service in Pennsylvania, the study found that the level of education influenced the employment of local job seekers over a two-year period in Counties considered. Job seekers with higher education and experience levels reported more job offers than job seekers with lower levels of education. Job seekers with a high school diploma reported $39 \%$ compared to $79 \%$ of people with a bachelor or advance degrees. These reports indicate a relationship between education level and poverty on the one hand and the ease of gaining employment.

\section{Comparing Education in Nigeria with other African Countries}

Public spending on education has been a source of concern for stakeholders in the education sector in Africa (Dahir, 2017; Olatunji, 2020). Over one-fifth of children between the ages 6 and 11 years are out of school, according to 2015 UNESCO Institute for Statistics (UIS) data. Governments in Africa need to increase public spending in education to reduce this gap and improve the young and the productive population of Africa. The education funding of countries like Ghana, Rwanda, and South Africa are evaluated to provide an insight into education funding in these countries in relation to Nigeria.

\subsection{Ghana: Public spending on Education as a percentage of public spending}

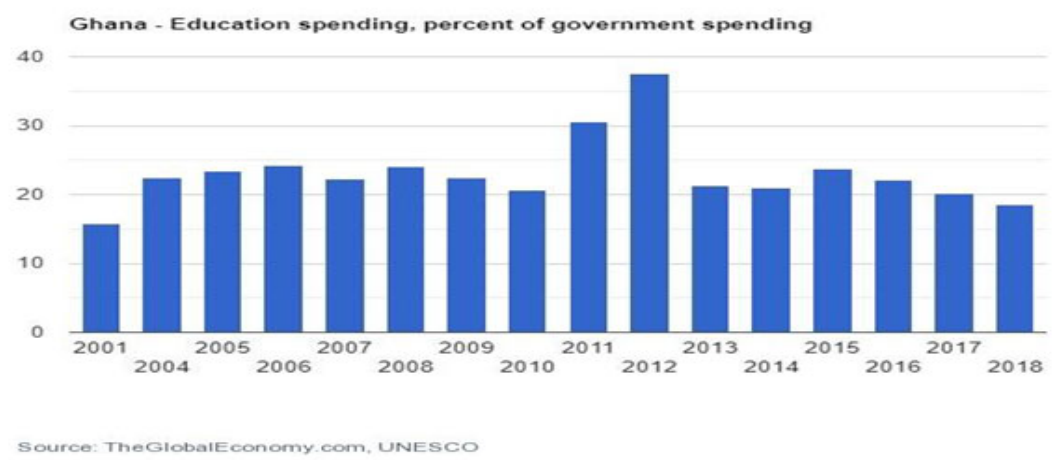

Figure 6: Ghana - Education funding, percent of government spending

As shown in figure 6, Ghana's average education spending in relation to national government's budget during the period was $21.62 \%$, with the lowest being $16.0 \%$ in 2001 and a peak of $38.0 \%$ in 2012. Ghana's poverty level has declined considerably from $28.2 \%$ in $2005 / 06$ to $18.2 \%$ in 2012 , due to the country's investment in education and the desire to meet the Millennium Development Goals (MDG) by focusing on 
income levels, poverty, hunger, primary school completion, and gender parity at schools (Debrah, 2013; Dzanku, 2015). With this effort, Ghana is on track to achieve the sustainable development goals (SDG) and increase the per capita income level to $\$ 3,000$. The decline in poverty is attributable to the increased funding of education by the government, which was consistently above $20 \%$ from 2004 to 2017.

\subsection{Nigeria: Public spending on Education as a percentage of public spending}

Figure 7: Nigeria's National Education Budget as \% of the National Budget

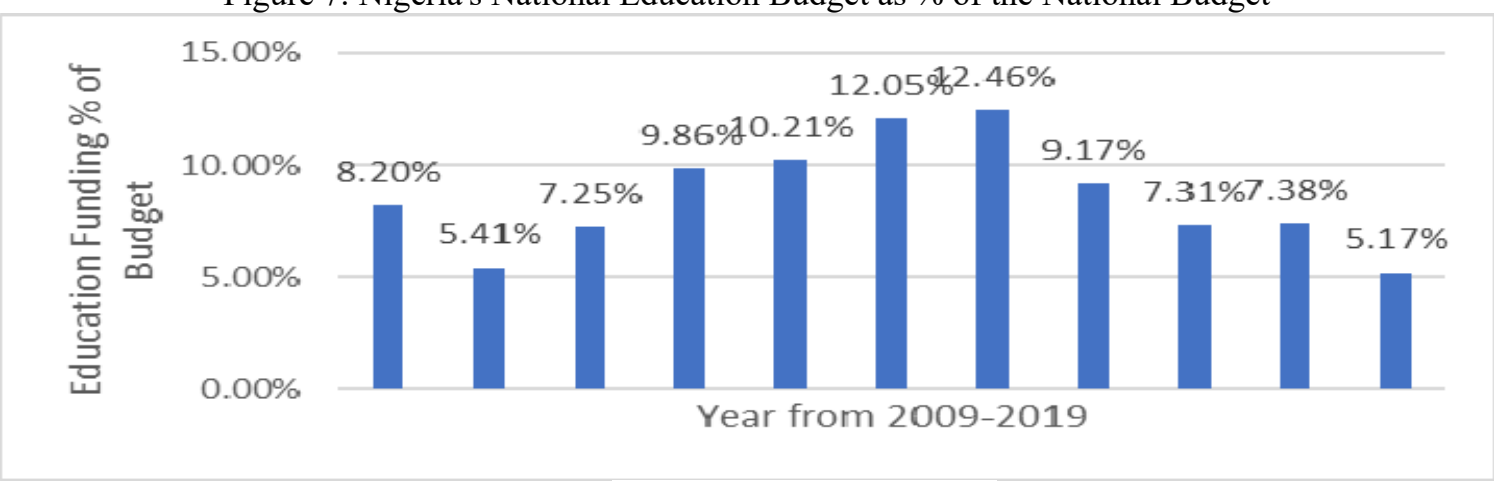

Source: Nigeria Bureau of Statistics

The percentage of education expenditure in Nigeria is relatively low, and the total expenditure to the education sector was $5.41 \%$ of the national budget in 2010 , as shown in figure 8 , compared to Ghana's $38 \%$ within the same period. The highest allocation to education funding within the period under review occurred in 2015 when the country allocated $12.5 \%$ to education. Consistently, Nigeria has distributed below the $15-20 \%$ recommended benchmark for education funding over the period.

To put this into perspective, a breakdown of allocations in 2010 shows that $53 \%$ of education funds were allocated to the compulsory primary education program, $25 \%$ to secondary education, and $22 \%$ for higher education. Most of the public expenditure (91\%) earmarked for formal education goes into covering the immediate costs of educational institutions and (9\%) as financial support to students and families.

\subsection{Rwanda: Public spending on Education as a percentage of public spending}

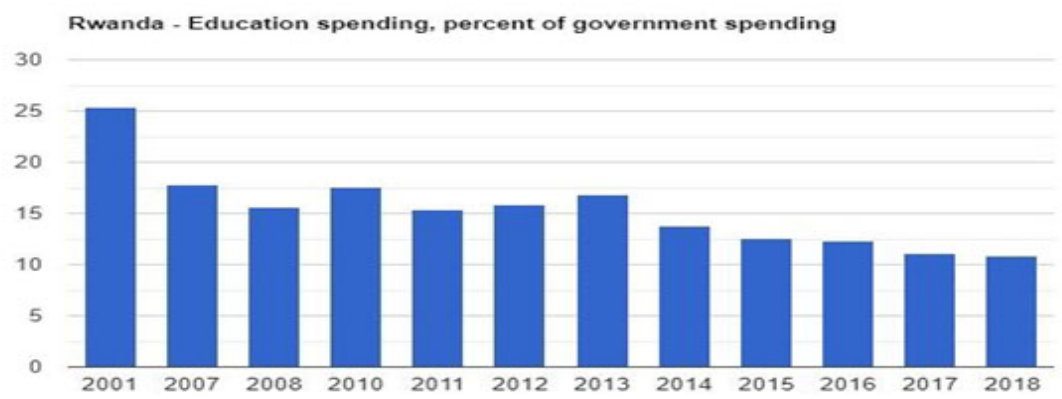

Figure 8: Rwanda - Education funding, percent of government spending

As shown in figure 8, the average education spending for Rwanda from 2001 to 2018 in relation to that of government budget during the period was $16.0 \% \%$, with the minimum being $11.0 \%$ in 2018 and a maximum of $25.31 \%$ in 2001. However, the sector's funding had dropped significantly from a peak of $25 \%$ in 2001 to less than $50 \%$ of the peak value to about $11 \%$ in 2018. Rwanda has consistently budgeted below the $15 \%$ benchmark since 2014 , with a yearly percentage decrease to the $11 \%$ mark in 2018 . Moreover, several of the years with the critical period of 2010 - 2019, which is the period of focus in our study, Rwanda barely reached or surpassed the $15 \%$ mark, none reached the $20 \%$ benchmark, which is the upper limit of the recommendation. The consistent drop in percentage allocation to education funding within the period could be traceable to funding gaps in critical sectors. As shown in figure 10, the poverty level dropped from about $45 \%$ in 2010 to about $38 \%$ in 2013 and remained within that level until 2016, and this was when the country's funding of education dropped below the 15\% mark. Figure 10 shows that Rwanda's best years for poverty reduction were from 2005 to 2013 , when Rwanda achieved a consistent and significant drop from about $56 \%$ to $38 \%$ within eight years. Correspondingly, this was the period that Rwanda allocated about $20 \%$ of its national budget to the education 
sector, as shown in figure 8 .

\subsection{South Africa: Public spending on Education as a percentage of public spending}

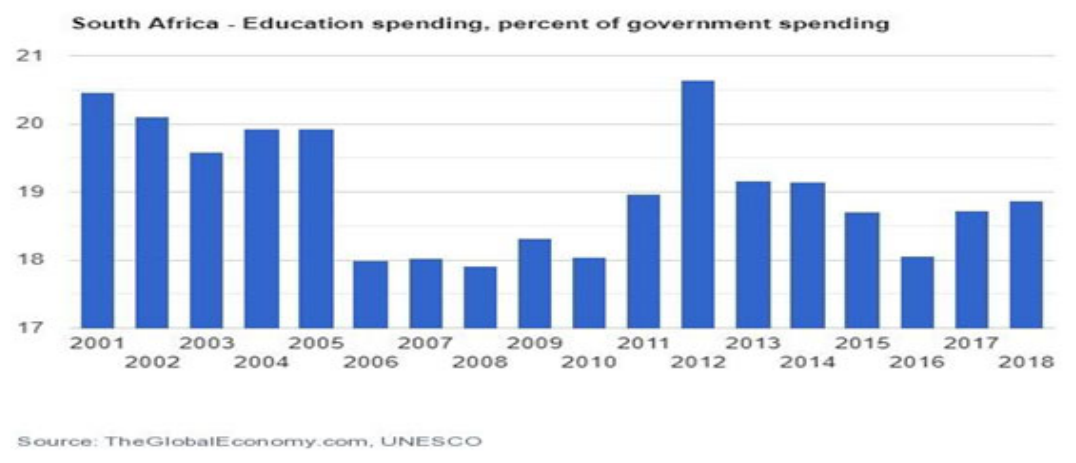

Figure 9: South Africa - Education funding, percent of government spending

As shown in Figure 9, the average spending on education for South Africa from 2001 to 2018 in relation to that of government budget during the period was about $19.0 \%$, with the lowest being about $18 \%$ in 2008 and a peak of $21.0 \%$ in 2012. Allocations to the education sector in South Africa have been above the lower limit of the 15 $20 \%$ UNESCO recommendation since 2001, with the best years occurring between 2001 and 2005 when the sector received an average of $20 \%$ funding. As shown in figures $9 \& 10$, poverty levels reduced significantly between 2006 and 2010 when the average allocation to the education sector was $18 \%$. South Africa witnessed an increase of $5 \%$ in poverty levels from 2011 to 2014 , as shown in figure 10 . This period corresponds to when South Africa started reducing allocation to the education sector, as captured in figure 9.

\subsection{Poverty Rates in Ghana, Nigeria, Rwanda, and South Africa}

Figure 10: Poverty rates in Ghana, Nigeria, Rwanda, and South Africa

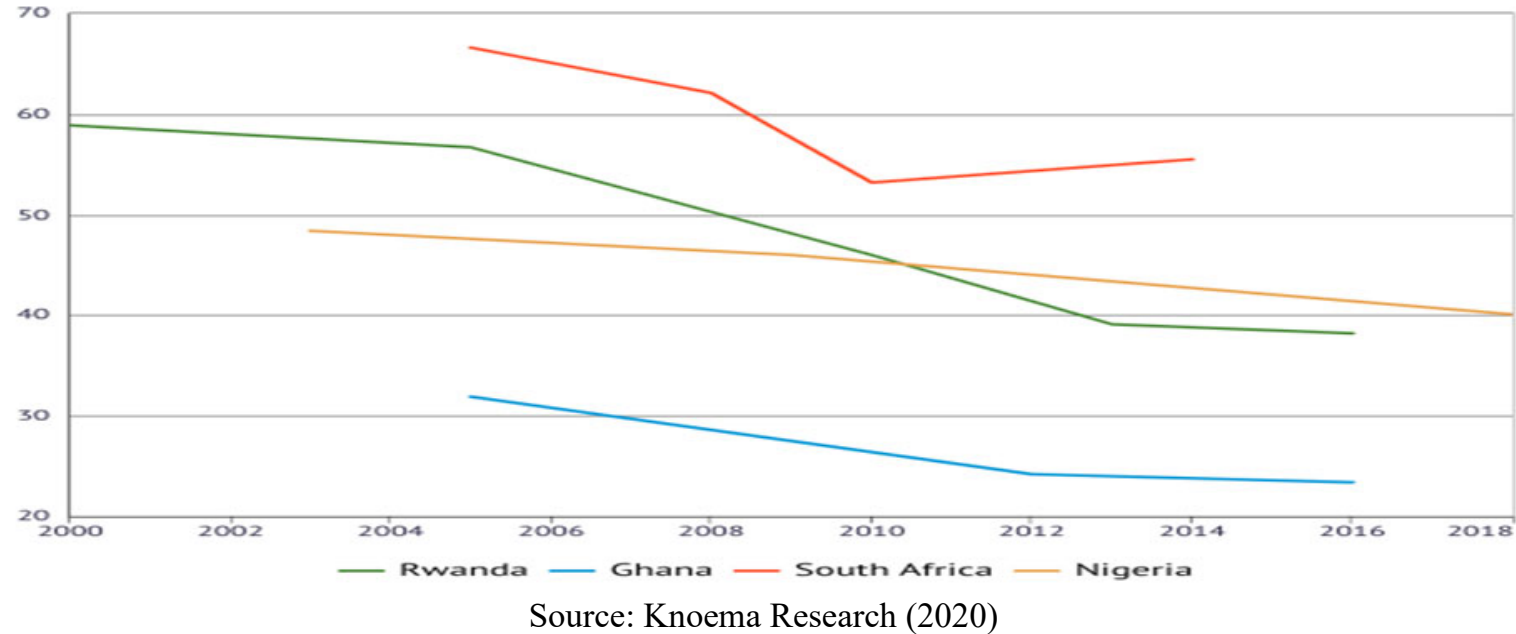

As shown in figure 10, the national poverty line for Rwanda in 2016 was $38.2 \%$, improving from a peak of $58.9 \%$ in 2000 . This is attributable to the above $15 \%$ average public spending on education over the last two decades, as shown in figure 8. Nigeria also witnessed a decline in the poverty line over a ten-year period from $48 \%$ in 2003 to $40 \%$ in 2018 ; the reduction could have been significantly below the $40 \%$ mark had the country invested more in education within the period. The drop falls short compared with Ghana, which witnessed a decline in the poverty line from $32 \%$ in 2005 to $23 \%$ in the same period.

The quality of education in Nigeria remains low when compared with the other African countries in our analysis. Furthermore, evidence suggests that the quality of primary education in Nigeria has deteriorated since the mid-2000s relative to other countries selected in this study. Poverty levels in Rwanda and South Africa stood at $39.1 \%$ and $16.6 \%$, respectively, within the same period, compared to $70 \%$ in Nigeria.

Contextually, Nigeria has about 200 million people, Ghana 29 million, and Rwanda 12 million. Nigeria's high population size means that the number of people living below the country's poverty line is twice the combined population of Ghana and Rwanda. Nigeria needs to devote more funds to education and encourage private sector participation in education through incentivized investment initiatives to attract private sector 
capital.

Also, there is a mismatch between the classrooms' size and the number of students in the classroom. Nigeria has a challenge of cramming too many students in one classroom against the stipulated pupil-teacher ratio advised by UNESCO of 25 students to one teacher (Bradley and Green, 2020; Lurani, 2012). Even when the classrooms are available, most are in deplorable conditions not conducive for teaching and learning. These are additional factors contributing to poor quality education in Nigeria.

\section{Findings and Recommendations}

Our findings show that the inadequate funding of the education sector in most parts of northern Nigeria is responsible for the high number of out-of-school children in that region. Our study aligns with the United Nations Children's Fund (UNICEF) findings in 2018, where they found that the population of out-of-school children in Nigeria has risen from 10.5 million to 13.2 million, mostly from the North East region of the country. There is a wide gap in education funding between most states in the southern part of the country compared to the northern states except for Kaduna state, which has reversed the trend since 2015. On average, most states in the country are spending below UNESCO's recommended 15-20\% allocation to the education sector. Drawing from the other African countries analyzed in the study, we find a link between increased funding to education and reduction in poverty indices in the country. Ghana increased funding to education above $20 \%$ for over a decade leading to a decrease in poverty levels, as indicated in figures 6 and 10.

A regional disparity exists among the six geopolitical zones in Nigeria. The three southern geopolitical zones have higher average annual budgets compared to the three northern geopolitical zones. The study recommends a deliberate increase in public funding for education by national and sub-national authorities, especially the North-East geopolitical zone that has been ravaged by sectarian violence and insurgency for the last ten years. State governments should adhere to UNESCO's recommendation in funding education to address the inadequacies in the sector and boost access to quality education in the country. Due to the enormous gap created by years of underfunding, government must adopt a diversified funding mechanism that enables it to harness public and private sector funds and funds from development partners to improve investment in education.

\section{Conclusion}

This study provides a comparative review of education funding across geopolitical zones in Nigeria and draws a nexus between Nigeria's budgetary allocation to education and some selected African countries. We provided a detailed analysis of the education funding of the selected states across Nigeria, taking the highest and lowest education budget for each zone into consideration. A critical finding of this study is that poverty levels have increased in northern Nigeria due to the extremely low allocation to education. To address the funding gap, we recommend a diversified funding mechanism for governments to enhance allocation to the sector and improve the country's quality of education. Nigeria could leverage the benefits of qualitative education to improve the living standard of the citizenry. The study contributes to the body of knowledge by identifying a link between poverty, income inequality, and education. Thus, for Nigeria to experience poverty reduction and income equality, we recommend increased education funding to reduce mass illiteracy in the country, especially in northern Nigeria. The lack of archived data for Nigeria's education budget and those of the state governments was a major constraint for the study. Future researchers can extend this study by incorporating education funding from more states in their analyses.

\section{References}

Abideen, O. A., Adewale, A. A. \& Adeola S. E. (2013). Analysis of rural literacy as a panacea for socioeconomy development of Nigeria, Academic Journal. 5 (9), 381-390. doi:10.5897/IJSA2013.0465

Akpan, U. \& Isihak, S. (2020). The geography of poverty in Nigeria. African Governance and Development Institute. 1-24. http://hdl.handle.net/10419/228009

Amechi C. (2020) Between poverty and insecurity in Nigeria. Retrieved from: https://www.vanguardngr.com/2020/08/between-poverty-and-insecurity-in-nigeria/

Arndt, C., McKay, A., \& Tarp, F. (2016). Growth and poverty in sub-saharan Africa. World Institute for Development Economics Research. Oxford University Press. Oxford.

Bradley, S \& Green, C. (2020). The economics of education: A comprehensive overview. doi:10.1016/C2017-002304-2

Brady, D (2019). Theories of the cause of poverty. Annual Review of Sociology. (45) 155-175. doi.org/10.1146/annurev-soc-073018-022550

Budget Office of the Federation. Nigeria federal budget 2010 - 2019. Available: http://www.budgetoffice.gov.ng/.

Butler, P. (2018). What is the new UK poverty measure - and why is it needed? The Guardian; International Edition. Available: https:/www.theguardian.com/society/2018/sep/16/what-is-the-new-uk-poverty- 
measure-and-why-is-it-needed.

Dahir, A. L. (2017). Education in Action: Private education is growing faster than public education in Africa. Quartz Africa, 1. Available: https://qz.com/africa/979203/private-education-is-growing-faster-than-publiceducation-in-africa/

Davis, P. E., \& Sanchez-Martinez, M (2015). Economic theories of poverty: An overview of the main economic theories relating to the causes of and responses to poverty in the UK. Joseph Rowntree Foundation. Available from: https://www.jrf.org.uk/report/economic-theories-poverty

Davis, P.E \& Sanchez-Martinez, M. (2014). A review of the economic theories of poverty. National Institute for Economic and Social Research. (435) 1-65.

Day, A. (2019). How funding cuts and rising poverty are pushing schools to breaking point. Retrieved from: https://www.huffingtonpost.co.uk/entry/education-schools-funding-cuts-poverty-austerity_uk.

Debrah, E. (2013). Alleviating poverty in Ghana: The case of livelihood empowerment against poverty. Africa Today, 59(4), 41-67. doi:10.2979/africatoday.59.4.41

Dzanku, F. M. (2015). Transient rural livelihoods and poverty in Ghana. Journal of Rural Studies. 40, 102-110. doi.org/10.1016/j.jrurstud.2015.06.009

Feng, J (2014). How should we measure poverty? World Economic Forum. Retrieved from: https://www.weforum.org/agenda/2014/11/how-should-we-measure-poverty/

Gordon, D. (2005). Indicators of poverty \& hunger: University of Bristol. Expert Group Meeting on Youth Development Indicators United Nations Headquarters, New York. Retrieved From: https://www.un.org/esa/socdev/unyin/documents/ydiDavidGordon_poverty.pdf

Ibrahim, B. \& Mukhtar, J.I. (2017). An analysis of the causes and consequences of kidnapping in Nigeria. African Journal Online. 11(4) 1-10. doi:10.4314/afrrev.v11i4.11

Kamau, J. K., Rotich. G., \& Anyango, W. (2017). Effect of budgeting process on budgeting performance of state corporations in Kenya: A case of Kenyatta national hospital. International Academic Journal of Human Resource and Business Administration (IAJHRBA). 2 (3) 255-281. Available from: http://www.iajournals.org/articles/iajhrba_v2_i3_255_281.pdf

Kinyondo, A. \& Pelizzo, R. (2018). Growth, employment, poverty, and inequality in Tanzania. The Journal of Pan African Studies. 11, 3, 1-181.

King, E. (2011). Education is the fundamental to development and growth. Education for Global Development. Available from: https://blogs.worldbank.org/education/education-is-fundamental-to-development-andgrowth

Knoema Global Economic Outlook | Q2 2020 Explained - knoema.com. Available from: knoema.com/infographics/wxfgphc/knoema-global.

Kolawole, B. O., Omobitan, A. O. \& Yaqub, J. (2015). Poverty, inequality, and rising growth in Nigeria: Further empirical evidence. International Journal of Economics and Finance 7(2), 1-13. doi:10.5539/ijef. v7n2p51

Lurani, T. R. (2012). Influence of teacher-pupil ratio and learner characteristics on provision of guidance and counselling services in public primary schools in Kenya: a case study of Eldoret municipality. Moi University Digital Repository. Retrieved from: http://ir.mu.ac.ke:8080/xmlui/handle/123456789/223.

Mitana, J.V., Muwagga, A. M. \& Ssempala, C. (2018). Towards a holistic and relevant educational assessment in primary schools in Uganda. African Educational Research Journal, 6 (2) 58-68.

Mourshed, M, Farrell, D \& Barton, D. (2018). Education to employment: Designing a system that Works. McKinsey \& Company, 1-104.

Ndujihe, C. (2019). Scandalous poor funding: Education gets N4.57 trillion of N61.48trillion budget in 10 years. Available: https://www.vanguardngr.com/2019/01/scandalous-poor-funding-education-gets-n4-57-trillionof-n61-48trillion-budget-in-10-years/.

Olatunji, O.A. (2020) The comparative analysis of rankings in South African and Nigerian higher education systems. The Education Systems of Africa. 1-16. https://doi.org/10.1007/978-3-030-43042-9_34-1

Omodero, C. O. (2019). Government sectorial expenditure and poverty alleviation in Nigeria. Research in World Economy, 10 (1) 1-11. https://doi.org/10.5430/rwe.v10n1p80

OECD (2019). The organization for economic co-operation and development (OECD) Data. Inequality and house overcrowding. Available: https://data.oecd.org/inequality/housing-overcrowding.html\#indicator-chart.

Oshewolo, S. (2010). Galloping poverty in Nigeria: An appraisal of government interventionist policies. Journal of Sustainable Development in Africa, 12 (6). 264-274.

Partner Work Report (2018). The role of education in job seekers' employment histories. Retrieved from: https://www.partner4work.org/uploads/role_of_education_in_employment_history.

Ravallion, M. (2008). Global poverty and inequality: A review of the evidence. World Bank Publication. Retrieved from: https://doi.org/10.1596/1813-9450-4623.

Sen, A. (1983). Poverty and famines: An essay on entitlement and deprivation. Oxford Scholarship Online. Oxford University Press. Oxford, UK. 
Shweta, R. (2018). How to stop poverty: Seven effective actions. Borgen Project. Retrieved from: https://borgenproject.org/how-to-stop-poverty-actions/

Simpson, M., Tuck, N. \& Bellamy, S. (2004). Small business success factors: the role of education and training. Education Training. Retrieved from: doi/10.1108/00400910410569605/full/html.

Surajo, A. Z. \& Karim, Z. (2016). Unemployment and poverty in Nigeria: A threat to sustainable growth and development. International Journal of scientific research and management. 4 (11). 4919 - 4928. doi: $10.18535 / \mathrm{ijsrm} / \mathrm{v} 4 \mathrm{i} 12.2$

Tade, O. (2020). Poverty and widening inequality in Nigeria. Retrieved from: https://businessday.ng/opinion/article/poverty-and-widening-inequality-in-nigeria/

Taiwo, E. (2019). Stakeholders decry decay in Nigeria's education system. The Daily Times. Retrieved from: https://dailytimes.ng/stakeholders-decry-decay-in-nigerias-education-system/.

Thomas, S. \& Canagarajah, S. (2002). Poverty in a wealthy economy: The case of Nigeria, issues 2002-2114. Business \& Economics, 1- 36.

World Bank (2018). Poverty and shared prosperity 2018: Piecing together the poverty puzzle. World Bank Publication. Retrieved from: https://doi.org/10.1596/978-1-4648-1330-6.

World Bank (2020). Nigeria releases new report on poverty and inequality in country. Available: https://www.worldbank.org/en/programs/lsms/brief/nigeria-releases-new-report-on-poverty-and-inequalityin-country. 